\title{
Право на изобилие: западный вещизм в контексте "престижного потребления" в СССР в годы перестройки (вторая половина 1980-х гг.)
}

Аннотация статьи: В статье исследуется феномен западного вещизма в советском обществе времен перестройки. Анализируются легальные механизмы приобретения импортных вещей широкого потребления. Автор приходит к выводу, что оборот на вторичном рынке (комиссионная торговля) не был высок. Магазины, торговавшие на валюту и валютные сертификаты, олицетворяли собой миф о западном изобилии, но зачастую служили источником пополнения пустующих полок обычной розницы. Кооперативная и государственная торговая сеть в изучаемый период становилась основным каналом приобретения гражданами товаров иностранного производства. При этом импортный ширпотреб, входивший в концепт «престижного» потребления в СССР, являлся самоценным сам по себе, вне зависимости от своих потребительских качеств.

Zarys treści: W artykule zbadany został fenomen zachodniego materializmu w społeczeństwie radzieckim czasów pieriestrojki. Zostały przeanalizowane legalne mechanizmy nabywania importowanych przedmiotów szybkozbywalnych. Autorka doszła do wniosku, że obrót na rynku wtórnym (handel komisowy) nie był wysoki. Sklepy, handlujące za walutę i bony, uosabiały mit o zachodniej obfitości, ale często służyły za źródło uzupełniające puste półki zwykłego handlu detalicznego. W badanym okresie sieci handlowe - spółdzielcza i państwowa - stawały się głównym kanałem, którym obywatele nabywali zagraniczne towary. Przy czym przedmioty szybkozbywalne z importu, wchodzące w koncept "prestiżowej” konsumpcji w ZSRR, były wartością samą w sobie, niezależnie od swoich wartości konsumpcyjnych.

Outline of content: The article investigates the phenomenon of Western materialism in Soviet society during the period called "Perestroika" (meaning: reconstruction). The legal arrangements for the acquisition of imported consumer goods are analysed. The author concludes that the turnover in the secondary market (consignment trade) was not high. The shops selling the currency and the currency certificates were the embodiment of the myth about the Western abundance, but they often served as a source of replenishment of empty shelves of usual retail. Cooperative and state trading system during the analysed period became the main channel of the acquisition by citizens of goods of foreign manufacture. The imported consumer goods, an element of the concept of "prestige" of consumption in the Soviet Union, were a self-valuable in themselves, regardless of their consumer qualities. 
Ключевые слова: перестройка, потребители, вещизм, импортные товары, торговля

Slowa kluczowe: pieriestrojka, konsumenci, materializm, towary importowane, handel

Keywords: Perestroika, reconstruction, users, materialism, imported goods, trade

Поколение советских граждан 1960-х - 1970-х годов рождения, вступившее во взрослую жизнь в годы перестройки ${ }^{1}$, являлось первым, для кого бытовые удобства и модная одежда получили реальную легитимацию в обществе, перестав считаться излишеством. Его представители «больше ценили эстетические качества платья или престижный лейбл на джинсах и обуви, отказываясь носить вполне еще приличную одежду только потому, что она вышла из моды или пошита на неизвестной ивановской фабрике» ${ }^{2}$. К этому времени джинсы обосновались в гардеробе «нормальной» советской молодежи, а стремление одеваться в «фирму» уже не противоречило социалистической морали, а вполне сочеталось с интересом к учебе, работе и достижениям «высокой» культуры.

Социологические обследования зафиксировали взлет уровня потребительских притязаний горожан во второй половине 1980-х гг., в значительной степени обусловленный тем, что именно тогда для них оказалось референтным «западное» пространство, с более высокими стандартами уровня и качества жизни ${ }^{3}$. Свою роль сыграл и отказ на уровне официальной идеологии от стереотипного восприятия заграницы как потенциально опасной среды, для которой характерны взаимная ненависть и жажда наживы.

Импортные вещи, служившие подтверждением новой (но не менее мифологизированной) «западной» реальности, приобретали особую ценность в глазах советских потребителей. При этом они готовы были переплачивать не за конкретный «бренд» и даже не за отменное качество, а за фирменность, то есть за «западную» материальность продукта как такового 4 . В 1980-е торговля была затоварена радиотехникой, телевизорами, фотоаппаратами, парфюмерией отечественного производства. Но покупатели не спешили за ними

${ }^{1}$ Семенова В.В. Современные концепции и эмпирические подходы к понятию «поколение» в социологии // Отцы и дети: Поколенческий анализ современной России / сост. Ю. Левада, Т. Шанин. М.: Новое литературное обозрение, 2005, с. 99-100.

2 Журавлев С.В., Гронов Ю. Мода по плану: история моды и моделирования одежды в СССР, 1917-1991. М.: ИРИ РАН, 2013, с. 460.

3 Магун В.С., Энговатов М.В. Межпоколенная динамика жизненных притязаний молодежи и стратегий их ресурсного обеспечения: 1985-2001 гг. // Отцы и дети: Поколенческий анализ современной России / сост. Ю. Левада, Т. Шанин. М.: Новое литературное обозрение, 2005, c. 284.

4 Юрчак А. Это было навсегда, пока не кончилось. Последнее советское поколение. М.: Новое литературное обозрение, 2014, с. 387-388. 
в магазины, очарованные магией западной этикетки. Как объяснила это явление одна из продавщиц, «не импорт, вот и не покупают».

Приобрести желанную «фирму» можно было различными путями. В частности, советские граждане могли привезти некоторые вещи из заграничной туристической поездки. Число выехавших из СССР за рубеж туристов выросло с 1975 по 1985 гг. с 2,5 до 4,5 млн. чел. ${ }^{5}$. Процесс особенно оживился, когда в начале 1980-х гг. был разрешен индивидуальный выезд в соцстраны по приглашениям. Классический «пакет», привозимый экономившими на всем счастливчиками в 1970-е - начале 1980-х гг., включал в себя: замшевый пиджак (или дубленку), кассетный магнитофон и карманный томик Солженицына. Даже в 1988 г., возвращаясь из Чехословакии, искусствовед М.Ю. Герман был облачен в приобретенную здесь дубленку, на которую истратил все обменянные дома рубли и командировочные. Его не остановили слухи о раздеваемых на границе соотечественниках (вывоз меха и кожи был строжайше запрещен). Но таможенникам он оказался не интересен: «Наши в очередной раз выкрутили руки чехословацким братьям: все советские хотели дубленки, единственное, что еще можно было привезти из Братиславы или Праги» ${ }^{6}$. Большинство туристов все же, не имея достаточно средств, не покупали, а, большей частью, разглядывали товары на витринах и прилавках магазинов ${ }^{7}$.

Но реальный западный мир по-прежнему был недоступен большинству советских граждан. Для них, помимо нелегального рынка (где вещи приобретались из-под полы у фарцовщиков и спекулянтов), существовало несколько совершенно законных каналов приобретения импортного ширпотреба, прежде всего магазины госторговли, в том числе комиссионные ${ }^{8}$, и кооперации.

К началу 1986 г. в СССР работали 2781 комиссионный магазин, а также 17 магазинов по продаже скупленных у населения вещей 9 . Сдатчиками импорта являлись дипломатические работники, сотрудники торгпредств, моряки торгового флота и командировочные. Продавцы были прекрасно осведомлены о намечавшемся поступлении и могли позвонить (по знакомству,

${ }^{5}$ Исмаев Д.К. Туризм - путь взаимопонимания между народами. М.: Знание, 1977, с. 18.

${ }^{6}$ Герман М.Ю. Сложное прошедшее. СПб.: Печатный двор, 2006, с. 397, 623.

7 Чистиков А.Н. «Ладно ль за морем иль худо?»: впечатления советских людей о загранице в личных записях и выступлениях (середина 1950-х - середина 1960-х гг.) // Новейшая история России. 2011. № 1, с. 174.

8 А. Каценелинбойген в своем исследовании назвал рынок комиссионных товаров «розовым», поскольку возможность работников этих магазинов (несмотря на то что их работодателем являлось государство) самим устанавливать цены давала им возможность получать нелегальные доходы. Каценелинбойген А. Цветные рынки и советская экономика // Экономическая теория преступлений и наказаний. 2002. № 4. Ч. 2. Режим доступа: http://www. corruption.rsuh.ru/4-2/n4-02 (дата обращения: 10.04.2015).

9 Народное хозяйство СССР за 70 лет: юбил. стат. ежегодн. М.: Финансы и статистика, 1987, c. 489 . 
конечно), если ожидалось что-либо стоящее: «Через пару недель вернется «Березка» из Америки. Я отложу вам, если будет подходящее» ${ }^{10}$. Правила комиссионной торговли непродовольственными товарами, утвержденные приказом Минторга СССР 13 февраля 1986 г., разрешали прием на комиссию вещей не только у советских граждан, но и у иностранцев, лиц без гражданства и политэмигрантов. Однако многие обыватели имели определенное предубеждение в отношении ассортимента этих магазинов: они считали, что основу его составляют вещи поношенные и бывшие в употреблении. Поэтому оборот в этой сфере не был высок. А либерализация валютного законодательства и массовый завоз на рубеже 1980-1990-х гг. импортных товаров челноками для продажи на рынках послужили причиной заката комиссионок ${ }^{11}$.

Привилегированное меньшинство (граждане, работавшие за границей или получавшие гонорары за творческую деятельность в валюте) могло приобрести вещи заграничного производства на валютные сертификаты (в РСФСР в торговой фирме «Березка») ${ }^{12}$. Вместе с этими магазинами в СССР пришла европейская мода, именно они в свое время позволили «переодеться» советским стилягам ${ }^{13}$, поскольку, в отличие от комиссионок, предлагали новую и хорошо сшитую одежду.

В Ленинградское объединение фирмы в 1988 г. входило 22 магазина (19 - в Ленинграде, а также в Новгороде, Мурманске, Выборге). Из них 17 торговало на свободно-конвертируемую валюту, 2 - обслуживали дипломатический корпус в Ленинграде, 2 - держателей чеков Внешпосылторга, 1 - осуществлял посылочную торговлю советским коллективам, работавшим за границей. Установленный объединению на 1987 год план в 76050,0 тыс. руб., фактически был выполнен на 83031,3 тыс. руб. (или 109,2\%). Директор ленинградской «Березки» Макаров предлагал еще более расширить сеть предприятий, в местах наибольшего посещения иностранных туристов (в Петропавловской крепости, Русском музее, в Петродворце, на Московском вокзале и пр.), а также открыть в системе Росинвалютторга магазины по реализации неходовых промтоваров ${ }^{14}$. Для одних посещение «Березки», как островка подлинного капитализма, оставалось мечтой. Другие считали недоступность этих «священных заказников тогдашних VIP» - типичным

10 Андреева И. Частная жизнь при социализме: отчет советского обывателя. М.: Новое литературное обозрение, 2009, с. 139.

11 Бартлетт Дж. Fashion East: призрак, бродивший по Восточной Европе. М.: Новое литературное обозрение, 2011, с. 305.

12 Там же, с. 305 Валютные магазины существовали и в других социалистических странах: в Праге импортные товары продавались в магазинах Tuzex, куда люди отправлялись, если хотели побаловать себя модными джинсами или помадой Dior. B 1962 г. была основана подобная же восточногерманская сеть Intershop.

13 Коротков Ю., Литвинов Г. Стиляги. СПб.: Амфора, 2009, с. 187.

14 Справка о работе ленинградской торговой фирмы «Березка» в 1987 г. // Государственный Архив Российской Федерации (ГА РФ). Ф. 9527. Оп. 1. Д. 9530, л. 78. 
проявлением рутинной системы раздач и навсегда запоминали «мерзкое ощущение страха и унижения» от визита в них с нелегально обмененной валютой ${ }^{15}$.

Право торговать за валюту имело и Всесоюзное объединение Торгмортранс Министерства морского флота СССР. К середине 1980-х гг. его специализированные магазины («Альбатрос») имелись в 26 портовых городах. В 1987 г. их оборот по чекам Внешторгбанка составил 227 млн. руб. ${ }^{16}$ Цена ряда товаров в чеках при переводе на советские рубли оказывалась в 2-4 раза выше их цены в рознице. Например, на полуботинки (ФРГ) - по цене 15,76 инвалютных рублей была установлена цена в чеках Серии А с учетом 5 \% наценки в размере 16,60, что соответствовало розничной цене 132 рубля. В то же время в рознице такие полуботинки можно было купить (если повезет, конечно!) за 65 руб. Столь же дороги в пересчете на валюту были швейные машины, пылесосы, холодильники и пр.

Поэтому до 10-12 \% завозившихся в эти магазины импортных товаров попадали в разряд труднореализуемых. По данным ВО Торгмортранс, за 1986-1987 гг. в спецмагазинах было развалючено и передано в розницу для продажи работникам морских пароходств промтоваров на 5410 тыс. руб., продовольственных в 1987 г. - почти на 4 млн. руб. Только в апреле 1987 г. под предлогом отсутствия спроса Внешпосылторг разрешил объединению Росинвалютторг Главного управления торговли Москвы передать в розничную сеть товары на 2056,5 тыс. руб., в том числе 90 стереомагнитол «Тошиба» (на 49,2 тыс.), 587 музыкальных центров «Панасоник» (на 359,7 тыс.), 590 портативных магнитофонов «Панасоник» (на 106,8 тыс. руб.), 980 холодильников «Филипс» (на 1060 тыс. руб.) и другую электробытовую технику ${ }^{17}$.

По сути тем самым создавалась лазейка в получении дополнительных ресурсов дефицита для неспециализированной сети. Так, управление торговли Грузинского морского пароходства при годовом фонде продтоваров 1600 тыс. руб. в 1986 г. передало в розницу продовольствия (в том числе мяса, колбасы, рыбных деликатесов, кофе, спиртных напитков) на 1360 тыс. руб. ${ }^{18}$. Такая же ситуация была в управлениях Черноморского, Дальневосточного, Приморского морских пароходств.

Организация торговли на чеки единого образца возлагалась на Министерства внешней торговли и торговли СССР. Первое отвечало за поступление валюты от продажи чеков, но ответственности за реализацию товаров не несло. Предприятия торговли концентрировали внимание на планах

15 Андреева И. Частная жизнь..., с. 158.

16 Справка о результатах проверки работы ВО Торгмортранс Министерства морского флота СССР по организации розничной торговли на чеки Внешторгбанка СССР // ГА РФ. Ф. 9527. Оп. 1. Д. 9530, л. 8.

17 Там же, л. 18.

18 Там же, л. 10-11. 
товарооборота, не увязывая с планами валютных поступлений. В результате ежегодно продавалось чеков больше, чем выделялось товарных ресурсов. Житель Лиепаи Недомытко в ноябре 1987 г. обратился с письмом в газету «Известия»: «Получил я дома 250 валютных рублей, и начались мои беды. Ездит жена то в Ригу, то в Клайпеду в эти «Альбатросы» и возмущается до глубины души. В Риге пустые полки. В Клайпеде товара много, но все очень-очень дорого и товар плохой. Зато на пороге и за углом магазина полно вездесущих чернобровеньких с усиками пареньков, покупающих эти боны. Только и слышишь: «Чеки есть?», - за квартал встречают каждого идущего в магазин, предлагают по 10-12 рублей за инвалютный рубль. Но это же спекуляция!» ${ }^{19}$.

В 1987 г. от розничной торговли на иновалюты и специальные платежные средства (чеки Внешэкономбанка и Внешпосылторга) в доход государства поступило свыше 627 млн. инвалютных руб., в т.ч. 243,3 млн. в свободно конвертируемой валюте. Выручка от этих операций в два раза превысила валютные поступления от экспорта в капиталистические страны общесоюзных Министерств станкопромышленности, приборостроения, электротехнической промышленности и тяжелого машиностроения, вместе взятых. В то же время 915 тыс. туристов из капиталистических стран, посетивших СССР в 1987 г., заплатили за товары 91 млн. инвалютных руб. или только 100 руб. на человека ${ }^{20}$. Таким образом, большая часть валютной выручки поступила от советских граждан.

Ориентация на импорт (в «Березках» и «Альбатросах» отечественные товары составляли 8-10 \%) привела к тому, что для обеспечения товарами государство ежегодно расходовало на их закупку за рубежом около 160 млн. инвалютных руб., в том числе почти 130 млн. в свободно-конвертируемой валюте. Однако расходовались они нерационально. Внешпосылторг производил закупку без участия торговых организаций. В результате залежавшиеся товары передавались на внутренний рынок. За 1986-1987 г. снималось для реализации во внутренней торговле импортных товаров по неполным данным на 35 млн. руб. ${ }^{21}$ Фактически валютные магазины, с одной стороны, служили каналом приобретения пусть и дорогих, но качественных товаров, с другой - становились в условиях дефицита источником пополнения пустующих полок обычной розницы.

Граждане, не имевшие ни валюты, ни чеков, с подозрительностью и даже негативизмом относившиеся к фарцовщикам и спекулянтам, не имевшие блата в комиссионках, шли за покупкой в обычный государственный магазин.

Изъятая у населения посредством «Березок» и «Альбатросов» валюта шла на приобретение товаров широкого потребления для рядовых обывателей.

19 Там же, л. 12.

20 Справка о результатах изучения организации розничной торговли в стране на чеки и свободно конвертируемую валюту // ГАРФ. Ф. 9527. Оп. 1. Д. 9530, л. 158-159.

21 Там же, л. 162. 
В 1986 г. импорт в СССР составил 62587 млн. руб., в том числе 15853 млн. - из стран капиталистического лагеря, 41840 - из стран социалистической ориентации, 4894 млн. - из развивающихся стран ${ }^{22}$. В структуре импорта в 1986 г. пищевые продукты составили 17,1 \%, промышленные товары народного потребления - 13,4 \%. Для продажи населению поступило в СССР импортных тканей, одежды и обуви на 20 млрд. руб. ${ }^{23}$ В основном закупались товары, не выпускавшиеся отечественной промышленностью или объем производства, которых был недостаточен для потребностей внутреннего рынка. Кроме того, производство и закупка некоторых товаров в других странах осуществлялись «с целью высвобождения мощностей на предприятиях легкой промышленности Советского Союза для выпуска более сложного ассортимента». Жительница Риги Г. И. Шорохова призывала «порадоваться» за нее сотрудников газеты «Известия»: «У нас тепло, а я купила настоящую заграничную одежду и теперь работаю в ней на огороде. Не подумайте, что я из современных миллионеров-кооператоров, раз ковыряюсь в земле в импорте. Нет, я из самого бедного сословия нашего времени - пенсионерка (мне 70 лет). А купила я всего-навсего телогрейку за 15 руб. и не на Дальнем востоке, а в городе Риге, Латвийской ССР. Почему об этом «восторженно» пишу? Да потому, что эта пресловутая телогрейка сшита в КНДР... синяя, фасона времен войны, покрытая дешевой тряпкой. Чем прельстились наши внешнеторговцы?». Ответ из Министерства торговли, куда редакция переправила письмо, гласил, что телогрейки на предприятиях Северной Кореи производились из отечественных хлопчатобумажных тканей в соответствии с межправительственным соглашением ${ }^{24}$.

Но, очевидно, продукция советской легкой промышленности не удовлетворяла потребности притязательного советского потребителя. СССР ежегодно ввозил порядка 300 млн. штук швейных и трикотажных изделий, 130 млн. пар обуви, на 45 млн. руб. шубно-меховых изделий, 120 млн. метров тканей, а также продтовары. Их удельный вес в рыночных фондах страны составлял: по обуви - $35 \%$, кожгалантерее - $30 \%$, трикотажным изделиям - $28 \%$, швейным - $23 \%$, шубно-меховым - $15 \%$, мясу и мясопродуктам - $5 \%$, сухому молоку - $30 \%$. В Москве, Ленинграде и других крупных городах доля импортных товаров в розничной торговле была значительно выше $e^{25}$.

${ }^{22}$ Народное хозяйство СССР..., с. 640.

23 Там же, с. 647.

24 Информация о работе с предложениями, заявлениями, жалобами граждан, поступившими в Министерство торговли СССР за 1988 год // Российский государственный архив экономики (РГАЭ). Ф. 465. Оп. 1. Д. 4880, л. 8.

25 Протокол заседания Междуведомственных советов по изучению спроса населения на товары народного потребления и рекламе при Министерстве торговли СССР // РГАЭ. Ф. 465. Оп. 1. Д. 5081, л. 53. 
Относительной самостоятельностью в закупке товаров обладал Центросоюз. Благодаря этому нередко даже очень модные вещи производства капиталистических стран продавались в сельских магазинах потребкооперации. По воспоминаниям И. Андреевой, здесь все могло лежать, стоять и висеть вперемешку: лопаты, чайные чашки, керосиновые лампы, плавленые сырки, пшено и гречка, женские лифчики, валенки гигантских размеров: «И вдруг! В углу, на неловких вешалках-плечиках - настоящий итальянский женский костюм из дивного шерстяного трикотажа! Или английское пальто из легкого мохера! Или французский джемпер - твоя давняя мечта! Или... да не может быть! - настоящие моднейшие итальянские сапоги! Эти сугубо советские фирменные «бутики»... первыми обнаружили модницы из многочисленных, густо чередующихся в Подмосковье Домов творчества от творческих союзов: писателей, кинематографистов, композиторов и т.д. Потом уж это стало вообще привычным делом - специально «прочесывать сельпо» ${ }^{26}$. Впрочем, скорее всего дело объяснялось не «модной» стратегией Центросоюза (в провинции именно он снабжал лавки сельской потребкооперации). Вероятно, причина оказывалась прозаичней: деревенским жителям не всегда были понятны новомодные изыски, да и не по карману. Схожие картинки наблюдались и в глубинке среднеазиатских республик, что вызывало бурю эмоций у заезжих командировочных: «Когда приходишь в магазины, на ярмарки, то глазам не верится, попадаешь в «рай», купить там можно все; импорта «горы», здесь и ветровки, и кофты, и пуловеры фирмы «Монтана» и обувь, футболки, плащи, пальто, ковры, хрусталь, косметика, белье и др.» ${ }^{27}$. Этот потребительский «рай» также объяснялся спецификой местного спроса: наиболее востребованы здесь были длинные панталоны с резинками, темных расцветок трикотаж и войлочные туфли. Столичные жители же судачили, что подобные привилегии республики получали из-за хлопка, и призывали прекратить их баловать: «Хотелось бы понемногу, но всем - импорта. Без обид! Справедливо! ${ }^{28}$.

Представляемые инофирмами коллекции образцов для розницы рассматривались межведомственными комиссиями, состоящими из специалистов Минвнешторга СССР, Минторгов СССР и союзных республик, Минлегпрома СССР, художников-модельеров Домов моделей, экспертов Торгово-промышленной палаты СССР. Для закупки товаров в странах социализма привлекались работники фирменных магазинов («Будапешт», «Прага», «Лейпциг», «Белград», «София» и др.). Особое место в структуре импорта занимали товары из Югославии. Работавшая во Всесоюзном институте ассортимента изделий легкой промышленности и культуры одежды И. Андреева

\footnotetext{
26 Андреева И. Частная жизнь..., с. 140.

27 Информация о работе..., л. 24.

28 Там же, л. 25 об.
} 
вспоминала, что «югославские товары, наряду с французскими, итальянскими или английскими, особо заказывались нашей торговлей для «спецмагазинов», то есть для высокого начальства» ${ }^{29}$.

В 1987 г. планировалась поставка: тканей хлопчатобумажных - 323,27 млн. метров (в том числе из Китая и Индии по 100, Пакистана - 35, Египта 5 млн. метров), шерстяных тканей 0,13 млн. метров, швейных изделий на 1337,42 млн. валютных руб. (в том числе из Вьетнама - 60, Корейской Народно-демократической республики - 102, Индии - 35, Финляндии 67,9 млн.), трикотажных изделий - на 639,3 млн. валютных руб. (в том числе из Китая - 28,5, Югославии - 47,5, Египта - 3, КНДР - 12 млн.), хрусталь - на 34 млн. валютных руб. (в том числе из ГДР - 1,5, из Польши - 1 млн.), бытовых электроприборов - 6,34 млн. валютных руб. (в том числе из Польши - на 0,46 млн.). Закупке подлежали также ковровые изделия, предметы женского туалета, косметика и парфюмерия ${ }^{30}$.

Однако в страну поступали отдельные партии товаров, не соответствовавшие образцам-эталонам, с нарушением контрактных обязательств по ассортименту, качеству, срокам поставки, сезонности. В 1986 г. польская фирма «Конфексим» завезла на Брестскую базу 23 партии (13 \% от общего объема поставки швейных изделий) с нарушениями шкалы размеров, 10 партий с нарушениями гаммы расцветок.

За 1984-1985 гг. инофирмыне поставили в установленные сроки товаров на 114 млн. переводных руб. ${ }^{31}$, что составило 33,2 \% от общей суммы подписанных договоров. Контракты на сумму 10,3 млн. руб. были аннулированы ${ }^{32}$. При общем выполнении плана поставки по большинству товаров поступление их в счет контрактов 1987 г. также проходило со значительным отставанием. Например, швейные изделия поступили лишь на уровне 45,7 \%, трикотаж $35,8 \%$, чулочно-носочные товары - 41,4 \%, кожаная обувь $-49,1 \% 33$.

Но далеко не всегда нарушители наказывались «рублем». В 1987 г. только за нарушение сроков поставки на три и более месяца не было предъявлено санкций на 1,2 млн. переводных рублей ${ }^{34}$. Руководители Союзимпортторга объясняли это тем, что иностранные поставщики тоже не предъявляли им штрафы за несвоевременный завоз. При этом не учитывалось, однако, что объемы недопоставленных советских товаров, оказались в три раза меньше, чем у инофирм.

29 Андреева И. Частная жизнь..., с. 139.

30 Протокол заседания..., л. 59.

31 Переводный рубль - коллективная валюта, средство платежа для взаимных расчетов стран Совета Экономической Взаимопомощи, утвержденный соглашением 22 октября 1963 г.

32 Протокол заседания..., л. 63.

33 Там же, л. 63.

34 О роли закупок товаров по импорту в деле более полного удовлетворения спроса населения на товары народного потребления // ГА РФ. Ф. 9527. Оп. 1. Д. 9002, л. 75. 
Система контроля качества импортных товаров не создавала серьезной преграды к проникновению в торговлю бракованной продукции. На иностранных предприятиях-поставщиках проверки осуществляли ОТК и, в лучшем случае, независимые контролирующие организации, не связанные никакими обязательствами с покупателем и не несшие материальной ответственности за результаты своей работы. В СССР контроль осложнялся ведомственными разногласиями между Госторгинспекциями Министерств торговли союзных республик и Торгово-промышленной палатой СССР, а также из-за отсутствия на практике единого на всей территории СССР подхода к оценке качества импортного ширпотреба.

Основная часть товаров иностранного производства проверялась на оптовых базах Минторгов союзных республик, приграничных базах Минторга СССР в г. Бресте и Львове и в розничной сети. Бракеры на торгово-закупочных базах разбраковывали по 10 \% от каждой партии швейных и трикотажных изделий; по обуви, радиоаппаратуре и посуде проводилась $100 \%$ разбраковка. По ее итогам часть некачественных товаров возвращалась поставщикам, часть - уценивалась по актам экспертизы. За 1986 год было предъявлено претензий инофирмам на 170,7 тыс. переводных рублей, за 1987 г. на 350,3 тыс. $^{35}$

За первый квартал 1987 г. Брестская и Львовская базы проверили 3805 тыс. условных единиц основных групп товаров, что составило 14,3 \% от поступления, против 3780 тыс. условных единиц (или 13,2 \%) в первом квартале 1986 г. Проверки показали, что качество импорта ухудшилось. Так, швейных изделий было проверено 830,3 тыс. штук из 6359,5 тыс., поступивших в первом квартале 1986 г. Процент забраковки составил 13 \%. В первом квартале 1987 г. из 5916,3 тыс. шт. проверено было 818,4 тыс. штук, из них 16,9 \% забраковано. По трикотажным изделиям процент забракованных товаров составил 19 и $23 \%$, соответственно ${ }^{36}$.

Много некачественных изделий поступало из ГДР, Венгрии. Например, предприятие «ФЕБ Квинтет Моден Глаухау» (ГДР) отгрузило на Брестскую базу женские пальто: из проверенных 2518 шт. забраковали 749 или 29,7 \%.

Не отличались высоким качеством трикотажные изделия предприятий «Смиродово» (СРР), «Эмин-Дурару» (СФРЮ), «Олимпия» (ПНР). Наибольшее количество некачественной обуви поступило от предприятий «ЗГК» (ЧССР), «Солидаритатя» (СРР), «Дуна», «Ендред» (ВНР), «Радоскур», «Отмент» (ПНР). Из-за низкого качества изделий в 1986 г. был аннулирован контракт на поставку обуви итальянской фирмы «Центроподукт». Покупатели жаловались на низкое качество даже хваленых югославских кожаных пальто (стоило поносить две недели, «как вся черная покраска облупилась, и оно стало

\footnotetext{
35 Протокол заседания..., л. 63.

36 Там же, л. 64.
} 
похожим на африканскую зебру») и мужских курток из искусственной кожи («после двух месяцев носки слезла местами кожа на вставке, которая закрывала молнию») $)^{37}$.

В 1986 г. с Брестской и Львовской баз было возвращено инофирмам брака на сумму 32,5 млн. руб., в том числе швейных товаров - 15 млн. руб. (0,09 \% от поступившего количества), трикотажных - 5,4 млн. (0,19\%), обуви - 10 млн. руб. $(0,85 \%)^{38}$.

У поставщиков, систематически нарушавших требования по качеству, прекращался прием товаров. В 1986 г. по этой причине не были закуплены швейные изделия в Югославии (предприятия «Каменско», «Чеба», «Обнова», «Эмин Дуреско», «Младость»); обувь в Румынии («Агнита», «Модерн»), трикотажные изделия из Венгрии («Казмю») и Австрии («Юримекс»). В 1987 г. прекращалась закупка или сокращались ее объемы: по обуви производства фабрик Румынии («Агнита» и «Модерн»), Венгрии («Апполо», «Фаворит», «Балатон»), Италии («Б.Б.М.»), по швейным изделиям Венгрии («Алкаташ», «Фламинго»), Румынии («Скоричешти»), Пакистана («Фатекс») и др. ${ }^{39}$.

Основная часть товаров выбраковывалась до продажи населению. Часть изделий (главным образом, обувь) возвращалась покупателями связи с проявлением скрытых производственных дефектов. В 1986 г. таким порядком было возвращено 223 тыс. пар, что составляло 0,2 \% от общего количества проданной импортной обуви ${ }^{40}$.

Практика закупок импортных товаров для обезличенного потребителя вела к неоправданному расходованию валютных средств, а также к появлению и постоянно растущим в государственной и кооперативной торговле запасам неходовых импортных товаров. По данным ЦСУ, на 1 октября 1986 г. они составляли 128,9 млн. руб. Минвшенторг СССР неоднократно подчеркивал, что отсутствие единого компетентного и авторитетного органа не позволяло своевременно информировать страны-поставщики о том, что именно требовалось потенциальному потребителю в СССР. Это в равной степени относилось и к розничной сети госторговли, и к валютным магазинам. В цепи «заказ-закупка-опт-розница» многие проблемы накапливались годами: планирование, отбор образцов, контроль качества, претензионная работа, порядок розничного ценообразования.

С 1 января 1987 г. право проводить экспортно-импортные операции предоставлялось 20 министерствам и 70 крупным предприятиям. Через год были ликвидированы Министерство внешней торговли и Государственный комитет по экономическим связям СССР и учреждено Министерство

\footnotetext{
37 Информация о работе..., л. 13a, 15.

38 Протокол заседания..., л. 64.

39 Там же, л. 50.

40 Там же, л. 5.
} 
внешнеэкономических связей СССР, которое стало лишь регистрировать предприятия, кооперативы и иные организации, ведущие импортные закупки. По воспоминаниям М.Ю. Германа, к концу 1980-х гг. привычные отечественные товары просто исчезли, зато в киосках «красовались ослепительные шоколадки и печенье в «импортной» упаковке... вкупе с дорогим и сомнительным барахлом («трудящийся востока», предлагавший барышням кофточки с клеймом «Puma», темпераментно восклицал: «Смотри, настоящая «Рита»!). Зато новые магазинчики торговали телевизорами, видеомагнитофонами и прочими разностями, виданными прежде лишь в «Березке», и практически только за валюту» ${ }^{41}$. При этом кооперативы развернули широчайшую спекуляцию товарами, скупленными в госторговле. Например, в магазине-салоне «Спейс» в Ленинграде женский костюм (Австрия), был выставлен на продажу за 800 руб., при том, что в торговле он стоил 170 руб.; бюстгальтер (Франция) по цене 60 руб. в госрознице стоил 13,50. За 500-590 руб. за флакон продавались духи и туалетная вода, а вельветовые джинсы (Италия), стоившие 100 руб., продавались за $313^{42}$.

В этих условиях «Березки» и «Альбатросы» перестали считаться островками товарного изобилия в море дефицита и отживали свой век. Из-за неудовлетворительной организации торговли, слабого товарного обеспечения, практически полного отсутствия службы услуг, неадекватной ценовой политики по состоянию на 1 января 1988 г. на руках у советских граждан имелось свыше 1,3 млрд. рублей в чеках Внешпосылторга, что было эквивалентно 400 млн. руб. в инвалюте ${ }^{43}$. В целях устранения негативных явлений, связанных с продажей товаров в специализированных магазинах на чеки Всесоюзного объединения Внешпосылторг и упорядочения обмена иностранной валюты, получаемой советскими гражданами, с 1 июля 1988 г. соответствующие магазины закрывались, в 1991 г. отменили и чеки для моряков ${ }^{44}$.

Западные вещи, органично входившие в концепт «престижного потребления» в СССР, были самоценны сами по себе, вне зависимости от своих потребительских качеств. Причиной очарованности советских граждан импортными товарами не являлся конфликт с политическим режимом как таковым, а скорее это было отражением мифологизации западного мира как общества всеобщего благоденствия. Привнесенная с Запада вера в естественное право на изобилие послужила идейной основой для формирования в России общества потребления. Вместе с тем широкое распространение

${ }^{41}$ Герман М.Ю. Сложное..., с. 648-649.

42 Сводный обзор к статистической отчетности Ленгоробуправления Госторгинспекции РСФСЗ за первый квартал 1991 г. // Центральный государственный архив историко-политических документов Санкт-Петербурга. Ф. 24. Оп. 243. Д. 84, л. 24.

43 Справка о результатах..., л. 158.

44 Иванова А.С. История торговой сети «Березка» в СССР (конец 1950-х - 1980-е гг.) // Российская история. 2012. № 5, с. 182. 
этого мифа, особенно в среде городской молодежи (у которой пиетет перед потребительскими ценностями Запада стал к середине 1980-х гг. признаком «хорошего тона») способствовало радикальному изменению и политической реальности в стране.

\section{Prawo do obfitości: zachodni materializm w kontekście „prestiżowej konsumpcji” w ZSRR w latach pieriestrojki (druga połowa lat osiemdziesiątych)}

\section{Streszczenie}

Artykuł dotyczy początków społeczeństwa konsumpcyjnego w czasach pieriestrojki oraz wartości, jaką dla mieszkańców ZSRR miały towary z importu, niezależnie od ich jakości czy marki. Autorka opisuje typy importu prywatnego i państwowego aż do rozluźnienia przepisów w końcu lat osiemdziesiątych oraz system handlu w sieciach walutowych i bonów. Dewizy, pozyskane od ludności (nawet dwukrotność wpływów z eksportu do krajów kapitalistycznych) przeznaczano na zakup importowanych towarów szybkozbywalnych do zwykłych sklepów, gdzie były dwu-czterokrotnie tańsze niż w walutowych. Do handlu detalicznego przekazywano też drogie towary słabozbywalne po „rozwalutowaniu” oraz część „wybraków”. Przedmioty z importu trafiały również do wiejskich sklepów spółdzielczych oraz republik Azji Środkowej. Przez cenę i niedopasowanie do lokalnych gustów nie cieszyły się one powodzeniem.

Do $50 \%$ zakontraktowanych towarów przychodziło $\mathrm{z}$ opóźnieniem, a brak synchronizacji i badań potrzeb rynku powodował powstawanie zapasów towarów niechodliwych.

Pojawiło się zjawisko spekulacji towarami importowanymi oraz bonami. Handel bazarowy i „mrówki” spowodowały upadek komisów i sklepów walutowych „Bieriozka” i „Albatros”, gdyż towary dostępne za walutę pojawiły się w normalnej sprzedaży.

\section{Right to the abundance: Western materialism in the context of "prestigious consumption" in the USSR during the Perestroika period (second half of the 1980s)}

\section{Summary}

The article investigates the beginnings of the consumption society in the Soviet Union during the period called "Perestroika" (meaning: reconstruction), and the value represented by goods imported from the West for Soviet people, regardless their quality of brand. The author describes the types of import, both private and official one, until some relaxation of laws by the end of the eighties, and a chain of hard currency trading system in Western currencies and special bank checks. Foreign currency from people (even twice as much as the export receipts from capitalist countries) was assigned for the purchase of easily selling off commodities in ordinary shops, where they were 2 to 4 times cheaper than in special Western currency shops. Also some expensive, not so marketable goods after they underwent currency denomination, and also some of rejected goods. Part of such commodities was sent to cooperative shops in the country and to shops in republics of Central Asia. But due to their high price and non-adjustment to local tastes they did not enjoy popularity.

Up to fifty percent of contracted goods were delayed, and the lack of market research led to the excess of not wanted, unmarketable commodities. As a result, there developed a phenomenon 
of "speculation" on imported goods and special bank checks. Trade at markets and the so-called "ants", i.e. trader-tourists, who were doing multiple frontier crossings each day caused the collapse of those consignment shops and special foreign-currency shops "Bieriozka" and "Albatros", for it became possible to buy Western goods in normal shops.

Translated by Grażyna Waluga

Е.Д. Твердюкова, доцент Института истории СПбГУ, доктор исторических наук, в 2004 г. окончила юридический факультет СПбГУ со специализацией по истории права России. В настоящее время в сфере внимания Е.Д. Твердюковой - изучение проблем социально-экономической истории, истории российской повседневности и правового развития России XX в. (e.tverdyukova@spbu.ru).

J.D. Twierdiukowa, docent Instytutu Historii SPbGU, doktor nauk historycznych (dr hab.), w 2004 r. ukończyła Wydział Prawa SPbGU ze specjalizacją historia prawa Rosji. Obecnie w sferze zainteresowań J.D. Twierdiukowej znajduje się badanie problemów historii społeczno-ekonomicznej, historii rosyjskiej codzienności i rozwoju prawnego Rosji XX w. (e.tverdyukova@spbu.ru).

E.D. Tverdyukova, assistant professor of the Institute of History of Saint Petersburg University, $\mathrm{PhD}$ in historical sciences (dr hab.), in 2004 she graduated from the Faculty of Law of SPU as researcher into the history of laws of Russia. Her current research interests include: socio-economic history, history of Russian everyday life, and the legal development of 20th-century Russia (e.tverdyukova@spbu.ru). 